\title{
Funeral practices and foodstuff behaviour: What does eat meat mean? Stable isotope analysis of Middle Neolithic populations in the Languedoc region (France)
}

\author{
Gwenaëlle Le Bras-Goude ${ }^{\mathrm{a}, *}$, Estelle Herrscher ${ }^{\mathrm{b}}$, Jean Vaquer ${ }^{\mathrm{c}}$ \\ a Laboratoire d'Anthropologie des Populations du Passé, UMR CNRS 5199 PACEA, Université de Bordeaux 1, Avenue des Facultés, 33405 Talence cedex, France \\ ${ }^{\mathrm{b}}$ Unité d'Anthropologie: Adaptabilité Bioculturelle, UMR CNRS 6578, Université de la Méditerranée, Faculté de Médecine, Secteur Nord, Bd Pierre Dramard, 13916 \\ Marseille cedex 20, France \\ ${ }^{\mathrm{c}}$ Laboratoire d'Archéologie TRACES, UMR CNRS 5608, Université de Toulouse, Maison de La Recherche, 5 allée Antonio Machado, 31058 Toulouse cedex, France
}

\section{A R T I C L E I N F O}

\section{Article history:}

Available online 3 March 2012

\section{Keywords:}

Neolithic

Languedoc

Mediterranean

Funeral practices

Diet

Isotope

Nitrogen

Carbon

\begin{abstract}
A B S T R A C T
The aim of this study is to reconstruct the dietary patterns and economic behaviours of Neolithic populations in the Northwestern Mediterranean using isotopic and archaeological data. Burials come from four sites located in Languedoc-Roussillon region in French Mediterranean area. These sites are dated from the Middle Neolithic period (ca. 4500-3500 BC). They represent the Chasséen culture, characterized by regional features, such as economy management, resulting from territorial control. For this investigation, a stable isotopes $\left(\delta^{13} \mathrm{C}\right.$ and $\left.\delta^{15} \mathrm{~N}\right)$ method has been used on 50 human bone collagens and 28 associated animal bones. This method provides direct dietary information on the protein consumed including the relative amounts of marine $v s$. terrestrial and animal $v s$. plant proteins in diets. Isotopic results are mainly compared to archaeological data to understand economic distinctions and potential social status variations between different groups using specific funeral practices, i.e. lithic chamber graves vs. domestic/funeral pits. Results show that individuals buried in lithic chamber graves and those buried in pits did not have the same dietary pattern. This result suggests a possible differentiation between two socio-economic groups, i.e. consumers of resources from herding and from farming. No aquatic food appeared to be routinely consumed by these individuals despite a relative close proximity to sea and freshwater sources. Moreover, these outcomes lead us to hypothesize that: (1) funeral practices could be linked to specific economies and/or (2) to different social status and that (3) burial type and foodstuff could be an expression of religious worship. Further research could include data from other areas, such as Spanish Catalonia where there are funeral structures similar to Languedoc lithic chamber graves.
\end{abstract}

(c) 2012 Published by Elsevier Inc.

\section{Introduction}

Food choices are one of features reflecting human behaviour and could be a means to shed light on power, control and hierarchy in past societies. It is generally accepted that social status could be revealed through analysis of diet (Lillie, 1997; Danforth, 1999) and funerary practices (Binford, 1972). But we must be aware of limits of such approach (Renfrew and Bahn, 2000; Parker Pearson, 2003). Indeed, Renfrew and Bahn (2000) explain, for instance, that materials buried with the deceased are not inevitably the materials used during the individual's life, and that the relationship between the role and the social rank of the individual and the artefact disposal must be carefully considered.

\footnotetext{
* Corresponding author.

E-mail addresses: hygee2@wanadoo.fr (G. Le Bras-Goude), estelle.herrscher@ univmed.fr (E. Herrscher), vaquerjean@aol.com (J. Vaquer).
}

However, this systemic approach has a great informative potential (Robb et al., 2001). In her synthesis of archaeological and ethnographical American studies, Danforth (1999) relates that dietary pattern differences may be at the centre of social and economic stratifications when biological and burial features are taken into account. She suggests, for example, that burial data, i.e. location, can be related to the economical status of an individual within a human group or that the social status of an individual, i.e. as leadership, may allow differential food access (e.g. to meat resources) from the other community members (Danforth, 1999). Several archaeological studies have undertaken comparisons between social status, burial practices and food supplies (e.g. Richards et al., 1998; Le Huray and Schutkowski, 2005; Jay and Richards, 2005; Linderholm et al., 2008). The results vary according to the period and location. For instance, the stable isotope study conducted on several Iron Age populations (ca. 5th century cal. BC) in Bohemia have shown that some individuals buried with weap- 
ons, considered as "warriors", had a different dietary pattern, with more animal protein intake than the others (Le Huray and Schutkowski, 2005). On the other hand, the combination of burial and stable isotope data on a Viking site in Sweden (ca. 8th century AD) does not indicate different dietary pattern between individuals buried in chambers (high status) and those discovered in more ordinary burials (Linderholm et al., 2008).

The aim of our study is to reconstruct the diet and economic behaviours of Neolithic populations in the Southern France (Languedoc region). Funerary data, symbolizing a social and/or economic identity are combined with dietary information provided by bone collagen stable isotopes. The aim is to highlight possible economic distinctions and relationship with environmental resources and to understand if there are different dietary patterns between human groups which could be linked to distinct funerary practices (Vaquer, 1998). This study involves human remains from the funerary site of Najac, Siran (Hérault), compared to data from the funerary site of Coste Rouge, Beaufort (Hérault) as well as on the two domestic sites with burials: Les Plots, Berriac (Aude) and Le Crès Béziers (Hérault).

\section{Archaeological context}

All sites are all located in the Languedoc region (France), ca. $20-80 \mathrm{~km}$ from the Mediterranean sea (Fig. 1) and belong to the Chasséen culture (Middle Neolithic, ca. 4500-3500 cal. BC). This period is characterized by a specific economy management resulting from territorial control and also by the diversity of the funerary practices, i.e. domestic pits, funerary pits, chamber tombs, collective burials (Fig. 2) and dog burials (e.g. Mahieu, 1992; Valentin et al., 2003; Loison et al., 2004). The dietary economy is comprised of herding and farming (Vaquer, 1990). Zooarchaeological studies reveals that food resources came from the domestic sheep, goat and cattle, for meat and dairy products, with a predominance of
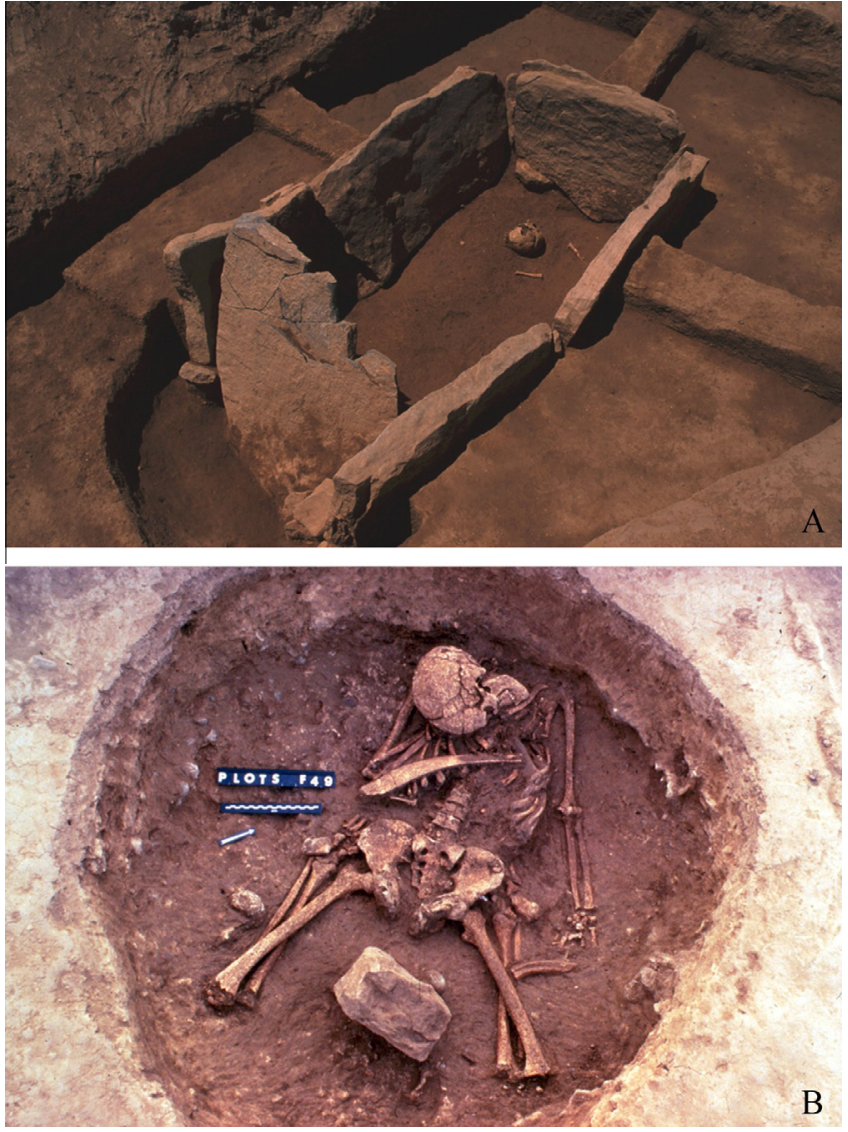

Fig. 2. A-Lithic chamber grave at Coste Rouge (๔ Jean Vaquer), B-domestic pit burial at Les Plots (๔ Jean Vaquer).

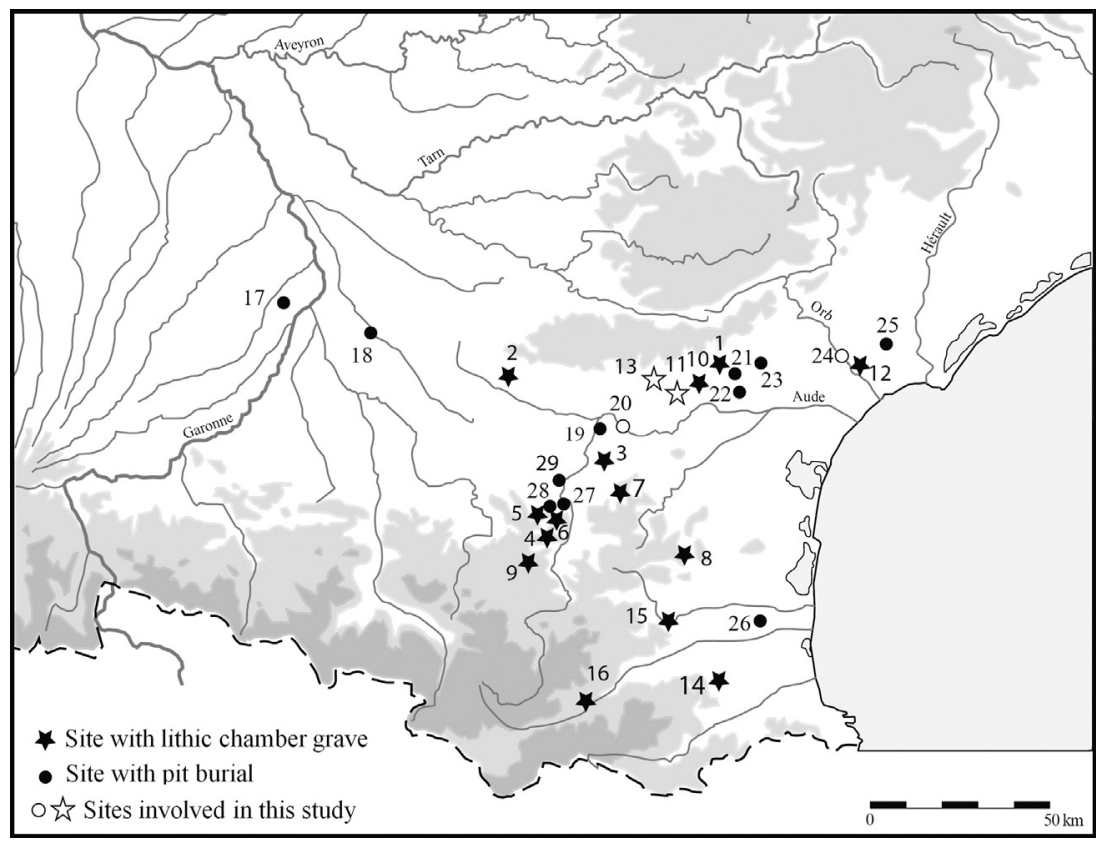

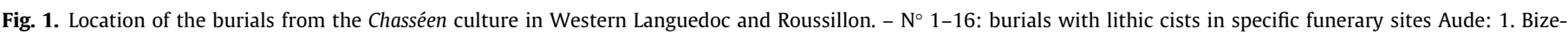

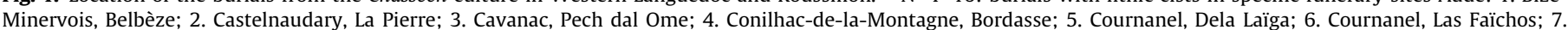

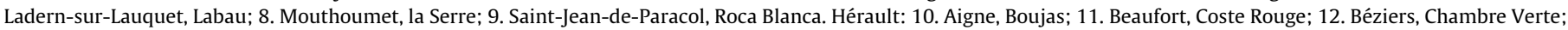

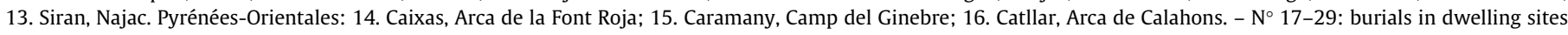

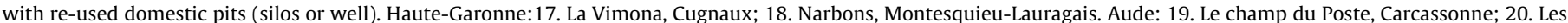

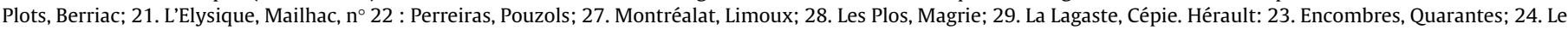
Crès, Béziers; 25. Le Pirou, Valros. Pyrénées-Orientales: 26. Chemin de Canohès, Perpignan. 
cattle in terms of meat weight (Forest, 2000; Carrère and Forest, 2003). Remains of pig and wild mammals are scarce. Very few shellfish remains were discovered in some sites, without evidence of marine and freshwater resources consumption (Forest in Loison et al., 2004). Cereals are the other main dietary staples. Agriculture may have been an important economic resource, highlighted by grindstone remains which were found in some burials (Loison et al., 2004).

Najac (Siran, Hérault) is a funerary site with four lithic chamber graves in which six individuals-five adults and one juvenile-were excavated (Mahieu, 1992). Very few faunal remains are associated with the deceased and there is no information regarding to diet via archaeological studies (e.g. archaeozoology, archaeobotanic). Three radiocarbon dates are available: $5354 \pm 50 \mathrm{BP}$ (Erl 12289), i.e. $4328-4050$ cal. BC, $5265 \pm 50$ BP (Erl 12290), i.e. $4233-3978$ cal. BC, $5268 \pm 50 \mathrm{BP}(\operatorname{Erl} 12291)$, i.e. $4233-3981$ cal. BC., indicating that the funerary deposits belong to the end of the Early Chasséen, ca. 4200-4000 cal. BC.

Coste Rouge (Beaufort, Hérault) is also a site dedicated to funerary practices, in which excavations brought to light one chamber grave (Fig. 2) with a child of 5-8 years old associated with very few faunal remains as funerary deposit (Vaquer et al., 2007). One radiocarbon date ( $4743 \pm 46 \mathrm{BP}, \mathrm{Erl} 9626$ ) indicates that the burial belongs to Late Chasséen culture (ibid.), i.e. 3638-3337 cal. BC.

Les Plots (Berriac, Aude) is the third site in the study. The burials: four domestic pits (silos) with three men and one woman (Fig. 2), were found in a dwelling (Duday and Vaquer, 2003). The faunal remains highlight the usual economic pattern for the region with a livestock of sheep, goat and cattle (pers. comm. I. Carrère). A radiocarbon date performed on a charcoal from the site: (Gif 9336) $5170 \pm 50$, i.e. $4210-3991 \mathrm{cal}$. BC and (Gif 9337) $5230 \pm 70$, i.e. 4238-3841 cal. BC, reports that the site was occupied during the Early Chasséen (Duday and Vaquer, 2003).

Lastly, Le Crès is the largest Middle Neolithic site, with burials $(n=30)$ associated with a dwelling space, located in the South of France (Loison et al., 2003, 2004; de Labriffe et al., 2007). The deceased are buried in domestic (silos) or funerary pits. The several excavations carried out by INRAP (French National Institute of Preventive Archaeology) exhumed 49 individuals: 27 adults (male and female) and 22 juveniles from different age categories. The zooarchaeological study also shows a herding with an emphasis on sheep/goat and cattle. Excavated botanical remains indicate that the farming is focused on wheat (Bouby in Loison et al., 2004). The radiocarbon dates from different graves indicate that the skeletal remains belong to the end of the fifth millennium cal. BC (G. Loison pers. comm.).

\section{Material and method}

Stable isotope analyses are now a routine process used in archaeology to reconstruct palaeodiet and human palaeobehaviour (e.g. Murray and Schoeninger, 1988). This method provides direct and individual dietary information on the protein intake (Ambrose, $1990,1993)$. The ratio of the stable isotopes of carbon and nitrogen (noticed $\delta^{13} \mathrm{C}$ and $\delta^{15} \mathrm{~N}$ ) allows researchers to reconstruct the type of environment from which individuals draw their resources (e.g., marine vs. terrestrial) and their place in the trophic web (e.g., herbivore, carnivore) (DeNiro and Epstein, 1978, 1981; Schoeninger et al., 1983; Minagawa and Wada, 1984; Ambrose, 1993).

Stable isotope $\left(\delta^{13} \mathrm{C}\right.$ and $\left.\delta^{15} \mathrm{~N}\right)$ method was used on 50 human bone collagens: six at Najac (this study), one at Coste Rouge, four at Les Plots (Herrscher and Le Bras-Goude, 2008) and 39 at Le Crès (Le Bras-Goude et al., 2009) (Table 1). Children under the age of ca. 3 years old were not sampled due to possible breastfeeding signal in bone collagen (Schurr, 1997; Herrscher, 2003). Indeed, infants consuming exclusively mother's milk have a carnivorous diet, and thus show higher stable isotope values than adults. In order to provide baseline data on the local ecosystem, faunal remains from the sites of Les Plots and Le Crès $(n=28)$ are also included in this study (Table 2). Taxonomic determination performed by the zooarchaeologists certified the analyses of the following species: sheep/goat, bovines (domestic and/or wild cattle), dogs, pigs (domestic or wild), red deer and roe deer.

Since no $\mathrm{C}_{4}$ plants were cultivated during the Neolithic period in the South of France (Marinval, 1988), it is possible to interpret $\delta^{13} \mathrm{C}$ value in bone collagen of ca. $-20.0 \%$ as a pure terrestrial protein intake (Schoeninger and DeNiro, 1984) while a value of ca. $-12.0 \%$ could be interpreted as pure marine protein intake (ibid.).Moreover, the human bone collagen $\delta^{15} \mathrm{~N}$ value indicates the relative importance of animal protein intake based on baseline isotopic data provided by a set of faunal species excavated from the same archaeological site (Bocherens and Drucker, 2003; Herrscher and Le Bras-Goude, 2010).

The bone collagen was extracted according to Longin's method (Longin, 1971) further adapted by Bocherens (1992). The isotopes $\delta^{13} \mathrm{C}$ and $\delta^{15} \mathrm{~N}$ express the ratio of the heavy isotope $\left({ }^{13} \mathrm{C},{ }^{15} \mathrm{~N}\right)$ to the light isotope $\left({ }^{12} \mathrm{C},{ }^{14} \mathrm{~N}\right)$ in a sample relative to international standards (IAEA) and expressed in \%o. Percentages of $\mathrm{C}$ and $\mathrm{N}$ and isotopic values were measured from $0.5 \mathrm{mg}$ of freeze-dried collagen and analysed with an IRMS ISOPRIME (VG Instrument) and elemental analyser NC 2500 Carlo Erba at the Department of Geology and Oceanography (EPOC UMR-CNRS 5805, University Bordeaux 1). Based on duplicate measurements the analytical precision

Table 1

Human stable isotope values, elemental compositions, $\mathrm{C} / \mathrm{N}$ ratios and extraction yield of well preserved sampled.

\begin{tabular}{|c|c|c|c|c|c|c|c|c|c|c|}
\hline Samples & Sites & Cultures & $\begin{array}{l}\text { Funeral } \\
\text { practices }\end{array}$ & $\begin{array}{l}\text { Yield (mg/ } \\
\mathrm{g})\end{array}$ & $w t \% C \pm 1 S D$ & $w t \% N \pm 1 S D$ & $\begin{array}{l}\mathrm{Cl} \\
\mathrm{N} \pm 1 \mathrm{SD}\end{array}$ & $\begin{array}{l}\delta 13 C \\
(\% o) \pm 1 S D\end{array}$ & $\begin{array}{l}\delta 15 \mathrm{~N} \\
(\% o) \pm 1 \mathrm{SD}\end{array}$ & References \\
\hline NH2 & Najac & Chasséen & $\begin{array}{l}\text { Chamber } \\
\text { grave }\end{array}$ & 49.0 & 37.3 & 13.6 & 3.2 & -19.6 & 9.3 & This study \\
\hline NH3 & Najac & Chasséen & $\begin{array}{l}\text { Chamber } \\
\text { grave }\end{array}$ & 42.7 & 35.3 & 13.0 & 3.1 & -19.5 & 9.7 & This study \\
\hline NH4 & Najac & Chasséen & $\begin{array}{l}\text { Chamber } \\
\text { grave }\end{array}$ & 37.0 & 35.8 & 13.4 & 3.1 & -19.8 & 10.3 & This study \\
\hline NH6 & Najac & Chasséen & $\begin{array}{l}\text { Chamber } \\
\text { grave }\end{array}$ & 10.6 & 32.8 & 12.4 & 3.1 & -19.7 & 8.7 & This study \\
\hline \multirow[t]{4}{*}{$\mathrm{T} 1$} & $\begin{array}{l}\text { Coste Rouge } \\
(n=1)\end{array}$ & $\begin{array}{l}\text { Late } \\
\text { Chasséen }\end{array}$ & $\begin{array}{l}\text { Chamber } \\
\text { grave }\end{array}$ & 42.3 & 35.2 & 12.7 & 3.2 & -19.0 & 10.8 & $\begin{array}{l}\text { Herrscher and Le Bras- } \\
\text { Goude (2010) }\end{array}$ \\
\hline & $\begin{array}{l}\text { Le Crès } \\
(n=19)\end{array}$ & $\begin{array}{l}\text { Early } \\
\text { Chasséen }\end{array}$ & Funeral pits & $58.7 \pm 37.0$ & $36.7 \pm 3.1$ & $13.7 \pm 1.0$ & $3.1 \pm 0.1$ & $-19.3 \pm 0.5$ & $8.0 \pm 1.0$ & $\begin{array}{l}\text { Le Bras-Goude et al. } \\
\text { (2009) }\end{array}$ \\
\hline & $\begin{array}{l}\text { Le Crès } \\
(n=13)\end{array}$ & $\begin{array}{l}\text { Early } \\
\text { Chasséen }\end{array}$ & $\begin{array}{l}\text { Domestic } \\
\text { pits }\end{array}$ & $45.8 \pm 34.3$ & $37.4 \pm 1.8$ & $13.5 \pm 0.7$ & $3.2 \pm 0.1$ & $-19.7 \pm 0.4$ & $8.2 \pm 0.5$ & $\begin{array}{l}\text { Le Bras-Goude et al. } \\
\text { (2009) }\end{array}$ \\
\hline & $\begin{array}{l}\text { Les Plots } \\
(n=1)\end{array}$ & $\begin{array}{l}\text { Early } \\
\text { Chasséen }\end{array}$ & $\begin{array}{l}\text { Domestic } \\
\text { pits }\end{array}$ & 10.6 & 36.7 & 12.9 & 3.3 & -19.6 & 8.8 & $\begin{array}{l}\text { Herrscher and Le Bras- } \\
\text { Goude (2008) }\end{array}$ \\
\hline
\end{tabular}


Table 2

Mean \pm 1 SD of animal stable isotope values, elemental compositions, $\mathrm{C} / \mathrm{N}$ ratios and extraction yield of well preserved sampled.

\begin{tabular}{|c|c|c|c|c|c|c|c|c|c|}
\hline Sites & Species & Cultures & $\begin{array}{l}\text { Yield (mg/ } \\
\mathrm{g})\end{array}$ & wt.\%C $\pm 1 \mathrm{SD}$ & wt. $\% \mathrm{~N} \pm 1 \mathrm{SD}$ & $\begin{array}{l}\mathrm{Cl} \\
\mathrm{N} \pm 1 \mathrm{SD}\end{array}$ & $\begin{array}{l}\delta^{13} \mathrm{C}(\%) \pm \\
1 \mathrm{SD}\end{array}$ & $\begin{array}{l}\delta^{15} \mathrm{~N}(\% o) \pm \\
1 \mathrm{SD}\end{array}$ & References \\
\hline Le Crès & $\begin{array}{l}\text { Herbivores/omnivores } \\
(n=8)\end{array}$ & $\begin{array}{l}\text { Early } \\
\text { Chasséen }\end{array}$ & $44.9 \pm 14.1$ & $32.8 \pm 4.4$ & $11.9 \pm 1.5$ & $3.2 \pm 0.1$ & $-19.8 \pm 0.7$ & $6.5 \pm 0.5$ & Le Bras-Goude et al. (2009) \\
\hline Le Crès & $\operatorname{Dog}(n=3)$ & $\begin{array}{l}\text { Early } \\
\text { Chasséen }\end{array}$ & $47.0 \pm 3.1$ & $36.1 \pm 3.4$ & $12.9 \pm 1.4$ & $3.3 \pm 0.0$ & $-19.5 \pm 0.1$ & $7.9 \pm 0.2$ & Le Bras-Goude et al. (2009) \\
\hline Les & $\begin{array}{l}\text { Plots } \\
5.9 \pm 0.4\end{array}$ & $\begin{array}{l}\text { Herbivores/ } \\
\text { omnivores } \\
(n=5) \\
\text { Herrscher } \\
\text { and Le } \\
\text { Bras-Goude } \\
(2008)\end{array}$ & $\begin{array}{l}\text { Early } \\
\text { Chasséen }\end{array}$ & $65.4 \pm 3.9$ & $30.8 \pm 1.3$ & & $10.9 \pm 0.3$ & $3.3 \pm 0.2$ & $-20.2 \pm 0.5$ \\
\hline
\end{tabular}

was below $0.3 \%$ for both C and N. Standards used were glycine, casein and acetanilid.

In order to detect contaminant and damaged collagen which could affect the stable isotope values (Bocherens et al., 2005a), the extracted collagen preservation was checked according to several preservation criteria: collagen yield greater than $1 \%$ (van Klinken, 1999); carbon content or equal to 30 weight\% (wt\%) and nitrogen content greater or equal to $11 \mathrm{wt} \%$ (van Klinken, 1999); and $\mathrm{C} / \mathrm{N}$ ratios between 2.9 and 3.6 (DeNiro, 1985).

\section{Results and discussion}

\section{Preservation state}

Amoung the six human samples at Najac only four have well preserved collagen (Table 1). With regards to the other sites, 49 (33 human and 16 faunal samples) were chosen based on their well preserved collagen (Tables 1 and 2). Considering samples all together $(n=53)$, the yield of extracted collagen ranges from $10.6 \mathrm{mg} / \mathrm{g}$ to $161.3 \mathrm{mg} / \mathrm{g}(51.3 \mathrm{mg} / \mathrm{g} \pm 29.5$ ), elemental compositions range from 29.3 to $42.0 \mathrm{wt} \%$ for carbon $(35.6 \% \pm 3.5)$ and from 10.4 to $15.5 \mathrm{wt} \%$ for nitrogen $(13.0 \% \pm 1.3)$. C/N ratios ranged from 2.9 to $3.5(3.2 \pm 0.1)$ and were within recommended values (DeNiro, 1985). Four collagen samples from Le Crès and Les Plots have lower carbon (29.3-29.7 wt\%) and nitrogen (10.4-10.7 wt\%) contents, but were very close to recommended values; the isotopic data are included but considered with caution (Herrscher and Le Bras-Goude, 2010). There is no significant correlation between the stable isotope values of the well preserved samples and these preservation criteria $(p<0.05)$. Thus, the ranges of stable isotope values do not appear to be linked to any kind of taphonomic process and may be used in palaeodietary studies (Bocherens et al., 2005a).

\section{Stable isotope values of animals}

Statistical descriptions of faunal stable isotope values are presented in Table 2. The $\delta^{13} \mathrm{C}$ for herbivore/omnivore species range from $-20.7 \%$ to $-18.4 \%$ ( $-20.0 \% \circ \pm 0.6, n=13)$ and the $\delta{ }^{15} \mathrm{~N}$ range from $5.7 \%$ o to $7.3 \%$ ( $6.3 \% \circ \pm 0.5, n=13)$. The carbon stable isotope values of animals range in the expected values for individuals living in temperate and $C_{3}$-plant environments (Bocherens, 1997). No marine resource (e.g. salt-marsh) were consumed by the sheepgoat, cattle and pig, suggesting that the coastal environment was not exploited for animal feeding (Balasse et al., 2005, 2006; Britton et al., 2008). Dog $\delta^{13} \mathrm{C}$ values range from $-19.6 \%$ to $-19.4 \%$ o $(-19.5 \% \circ \pm 0.1, n=3)$ and from $7.8 \%$ to $8.1 \% o(7.9 \% \circ \pm 0.2, n=3)$ for $\delta^{15} \mathrm{~N}$ values. As expected, the difference between stable isotope values of herbivores/pigs $(n=12)$ and dogs $(n=4)$ is in agreement with isotopic fractionation within the food chain (Mann-Whitney $U$ test: $p=0.02, U=6.5$ for $\delta^{13} \mathrm{C}$ and $p=0.00, U=0.0$ for $\left.\delta^{15} \mathrm{~N}\right)$, high- lighting the consumption of a significant amount of animal proteins by dogs. Likewise, there is no significant difference of faunal stable isotope values between sites. Thus, animal data can be considered together in order to define the isotopic baseline of this local ecosystem (Herrscher and Le Bras-Goude, 2010).

\section{Stable isotope values of Humans}

Najac human $\delta^{13} \mathrm{C}$ values range from $-19.8 \%$ to $-19.5 \%$ $(-19.7 \% \circ \pm 0.1, n=4)$ whereas $\delta^{15} \mathrm{~N}$ values range from $8.7 \%$ to $10.3 \%$ o $(9.5 \%$ $\pm 0.7, n=4)$. The average isotopic enrichment between humans from Najac and herbivores/omnivores from Languedoc $\left(\Delta{ }^{13} C\right.$ and $\left.\Delta{ }^{15} \mathrm{~N}\right)$ is $+0.3 \%$ for carbon and $+3.2 \%$ for nitrogen. Both stable isotope values and isotopic enrichments highlight that most of the protein consumed by humans at Najac come from the local terrestrial ecosystem. No marine and/or freshwater resources seem to be routinely consumed by this human group, as well as other sites in this region (Herrscher and Le Bras-Goude, 2010). This result is common for the Neolithic population in the South of France, in spite of the relative proximity to the sea for some sites (e.g. Le Crès, ca. $20 \mathrm{~km}$ from the sea) (Goude, 2007; Herrscher and Le Bras-Goude, 2010). The isotopic values recorded in the human bone collagen at Najac suggest also that meat and/or dairy products could be the main protein sources consumed by humans. The range of human $\delta^{13} \mathrm{C}$ values at Najac $(n=4)$ is very low $(0.3 \%)$, potentially indicating probably that the resources consumed by all these individuals came from food items characterized by a low isotopic range. The range of $\delta^{15} \mathrm{~N}$ values $(\Delta=1.6 \%)$ is in the range of values recorded amoung a human group with an omnivore diet in the study of O'Connell and Hedges (1999). This result suggests a difference of animal protein intake between some individuals from this group: the individual Najac_H6 has probably had a dietary pattern less rich in animal proteins than the others and particularly than the individual Najac_H4 who displays the highest $\delta^{15} \mathrm{~N}$ value $(10.3 \%$ ). A similar dietary pattern is suggested for the child of Coste Rouge (Herrscher and Le Bras-Goude, 2010). Interestingly, previous studies carried out on Les Plots and Le Crès sites revealed different dietary patterns with proteins coming from more mixed resources (vegetal and animal) and with varying animal protein intakes by individuals (Table 1) (Herrscher and Le Bras-Goude, 2008; Le Bras-Goude et al., 2009).

The statistical comparison between stable isotope values of humans from Najac $(n=4)$ and from Le Crès $(n=30)$ indicates that there is a significant difference between $\delta^{15} \mathrm{~N}$ values (Mann-Whitney $U$ test: $p=0.00, U=7.0$ ) while no difference was highlighted for $\delta^{13} \mathrm{C}$ values. Thus, two isotopic clusters can be defined: the first including data from Najac and Coste Rouge and the second including data from Les Plots and Le Crès (Table 1, Fig. 4). The statistical comparison between clusters confirms significantly high $\delta^{15} \mathrm{~N}$ values for Najac and Coste Rouge $(n=5)$ individuals in comparison to Les Plots and Le Crès individuals $(n=31)$ (Mann-Whitney $U$ test: 


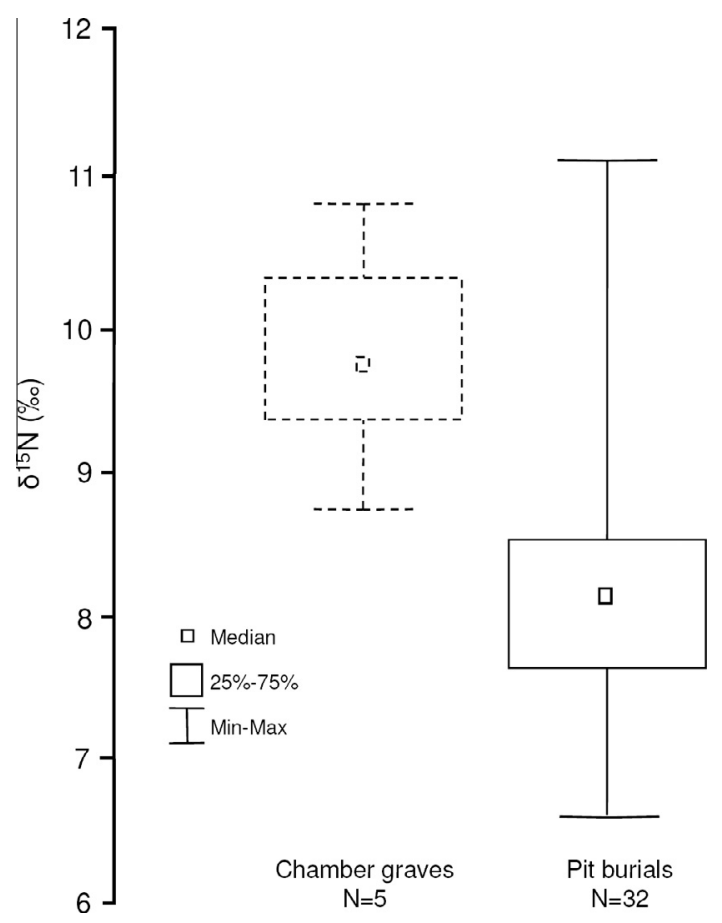

Fig. 3. Human and animal (medians and percentiles 2.5 and 97.5) collagen stable isotope values.

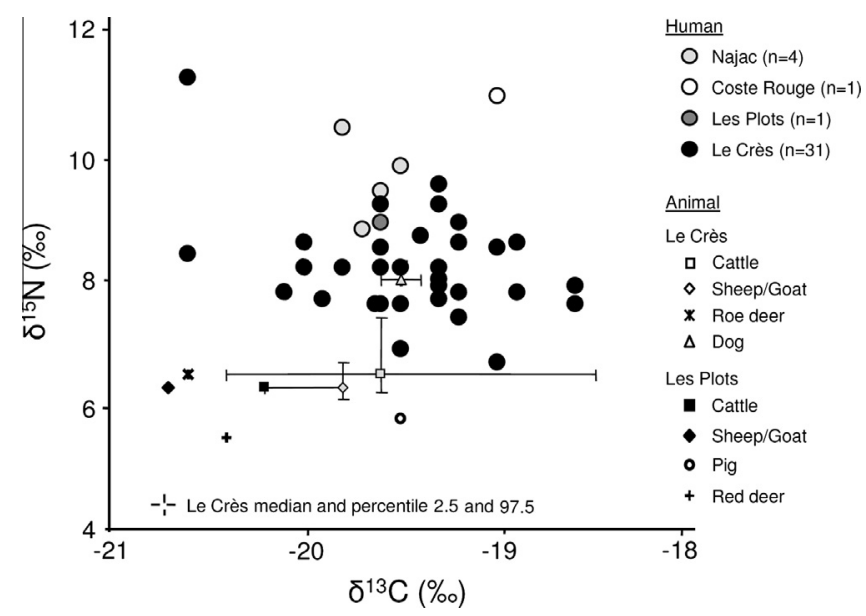

Fig. 4. Human and animal stable isotope results from the Neolithic sites of Najac, Coste Rouge (this study), Les Plots and Le Crès.

$p=0.00, U=8.0$ ). Is this observation reflecting a specific management of food resources according to environmental and economic constraints? Stable isotopes measured in bone collagen cannot discriminate protein sources from the same animal (i.e. meat, milk or cheese; Minagawa, 1992; O'Connell and Hedges, 1999) while zooarchaeological studies can provide more accurate information (Balasse et al., 1997; Helmer and Vigne, 2004; Helmer et al., 2005), however, concerning these Neolithic sites there is no information related to milk exploitation. Our first hypothesis suggests different dietary patterns between both groups in relation with distinct socio-economic context.

Additionally, the two groups practiced different funerary customs. The humans at Najac and Coste Rouge are buried in lithic chamber graves, while the humans at Le Crès and Les plots are buried in pits (Fig. 2). There is no isotopic discrimination between individuals buried in domestic and funerary pits at Les Plots and Le Crès. The second hypothesis to explain the significant difference of $\delta^{15} \mathrm{~N}$ values would indicate a distinct social status of individuals using specific funerary practices. This result suggests that individuals buried in lithic chamber graves would have consumed more animal proteins and/or proteins from resources with a high nitrogen stable isotope values than individuals buried in domestic or funerary pits (Fig. 3).

\section{Funerary practices and dietary patterns: application of a model}

In order to have more information about diet composition of these two groups, we applied a model using stable isotope data, performed by Phillips and Gregg (2001; IsoError @), available at http://www.epa.gov/wed/pages/models/stableIsotopes/isotopes/ isoerror1_04.htm) and by Phillips and Koch (2002; IsoConc @ , available at http://www.epa.gov/wed/pages/models/stableIsotopes/isoconc/isoconc1_01.htm). This model provides quantitative estimates of the proportions of food sources in consumer's diet insofar as stable isotope values of three different dietary poles (e.g. carnivore, herbivore and fish-eater) are known for the sites. This model must be used carefully (Ben-David and Schell, 2001; Robbins et al., 2002; Koch and Phillips, 2002; Richards et al., 2006), however, its application, within a well defined framework, is interesting to identify different food proportions and to propose more interpretations about the different isotopic signatures of humans. Several palaeodietary studies have previously used this model (Newsome et al., 2004; Drucker and Henry-Gambier, 2005; Bocherens et al., 2005a, 2005b; Bocherens and Drucker, 2006).

In this study, the first pole chosen is the local herbivores/pigs from Les Plots and Le Crès sites, as plant consumers, because it is assumed that usually local herbivores have isotopic values that reflect the local vegetation (Hedges and Reynard, 2007). The second pole is the carnivores, calculated with the isotopic values of local herbivores/pigs enriched by the theorical isotopic fractionation of ca. $+1.0 \%$ for $\delta^{13} \mathrm{C}$ and ca. $+4.0 \%$ for $\delta^{15} \mathrm{~N}$ (Bocherens and Drucker, 2003). Lastly, the third pole chosen is aquatic resource consumers. The $\delta^{13} \mathrm{C}$ of humans are different than values commonly recorded in bone collagen of marine fish eaters (Chisholm et al., 1982; Schoeninger and DeNiro, 1984), thus, the more pertinent aquatic resource should be freshwater fish. Freshwater fish consumers theoretically have $\delta^{13} \mathrm{C}$ values lower or close to isotope values of terrestrial resources consumers. In such a context and as the consumption of freshwater fish is often difficult to detect and so is underestimated (Hedges and Reynard, 2007), therefore it is pertinent to consider this dietary pole to run the model. Several studies have highlighted that isotope ratios in freshwater fish vary widely in relation to the nature and size of lakes/rivers (Dufour et al., 1999; Katzenberg and Weber, 1999; Leng et al., 2006). Based on these considerations, values from literature for freshwater fish from small sized European lakes were chosen (Dufour et al., $1999)$, with a correction $(+1.5 \%$; ) to avoid the "fuel effect" from modern values (Marino and McElroy, 1991; van Klinken et al., 2000).

The results of the model application are presented in the Fig. 5. The model clearly demonstrates that proportions of protein sources in diet differ amoung funerary groups. The individuals buried in lithic chamber graves might have consumed some freshwater resources but in very small proportion (probably less than 18\%), thus, it confirms that terrestrial resources were the almost exclusive food items in the human diet in this area. The individuals buried in lithic chamber graves have a higher proportion of terrestrial meat proteins in their diet (at least 37\%) than individuals buried in pits (at least 17\%). On the other hand, individuals buried in pits have a higher proportion of plant and/or legume proteins in their 


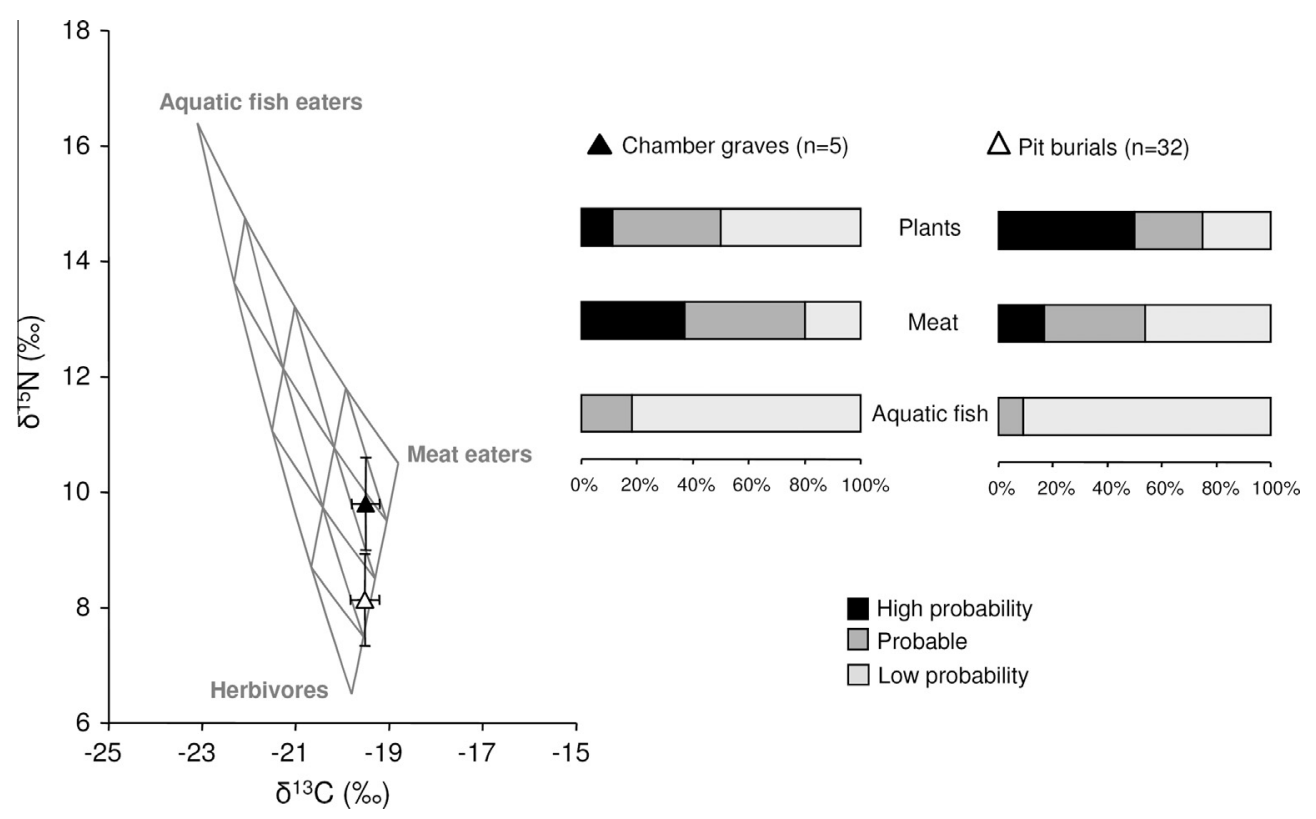

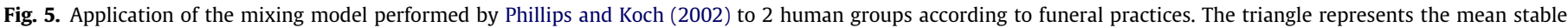
isotope values for consumers of $100 \%$ of 3 different dietary poles (plants, meat and aquatic fish). The model gives also the range of proportion of the 3 food poles.

diet (at least 50\%) than these buried in lithic chamber graves (at least $10 \%$ ). These results confirm the hypothesis suggested previously which proposed distinct dietary patterns according to the funerary group. The difference of animal protein intake between these groups is not linked to aquatic resources but to meat consumption. If one accepts the link between food production and food consumption, then the both funerary groups would have different food economies: composed of breeding for the individuals buried in lithic chamber graves and turned toward farming for the individuals buried in pits. Additionally, if one accepts relationship between beliefs and funerary practices, dietary patterns could also reflect behaviours regarding "religious" worship (Müldner and Richards, 2005; Vaquer, 2007). Is such isotopic evidence for relationship between funerary practices and dietary patterns specific to the Middle Neolithic in the Languedoc region? Similar studies performed in a wider area including Middle Neolithic populations from Garonne and Languedoc regions, did not reveal any relationship between dietary and funerary data (Herrscher and Le Bras-Goude, 2010). In contrast with the study of Linderholm et al. (2008), the relationship demonstrated above illuminates important information for palaeobehaviour studies and allows researchers to expand hypotheses, taking into account data such as body position and treatment, grave goods and structures. In addition, more archaeological evidence, especially further botanical studies, should be carried out in order to discuss more precisely our isotopic results. Furthermore, detailed zooarchaeological studies, including the discussion of proportions of animal species, may be useful in refining the accuracy of the linear mixing model (Drucker and Henry-Gambier, 2005). A combination of palaeoenvironmental, anthropological and isotopic information is the best way to propose pertinent hypotheses regarding the foodways and funerary behaviours of Neolithic populations and their beliefs in relation with the death.

\section{Conclusion}

Our stable isotope study provides specific data about foodstuff of Neolithic populations in the Languedoc region. It illuminates the intersection between stable isotope and archaeological datamainly funerary practices-to understand the impact of social fac- tors on dietary behaviours. This method provides the only the only methodological analyses to discover dietary information for sites without domestic context and with scarce zooarchaeological remains (Najac, Coste Rouge). The human dietary patterns appear to show a food supply mainly biased toward the terrestrial environment. Except potential freshwater protein intakes by some individuals, no aquatic food appears to have been routinely consumed despite a relative close proximity to the sea and rivers. The statistical approach shows a clear-cut difference in food choices according to the funerary practices. Two groups are highlighted: one with an important consumption of meat and/or dairy products for the individuals buried in lithic chamber graves and the other with a lower proportion of animal proteins and a greater proportion of vegetal resources (plant and/or legume) for the individuals buried in domestic (re-used silos) and funerary pits. These results suggest two hypotheses: either (1) funerary practices could be linked to specific economy and/or to different social status, or (2) burial type and dietary patterns might be an expression of religious worship. Additional information could be gained from an enlargement of data from studies of other areas, such as Spanish Catalonia where there are funerary structures similar to Languedoc chamber graves (Solsonian group).

\section{Acknowledgments}

The authors thanks Karine Charlier, Isabelle Billy, Philippe Martinez (EPOC UMR CNRS 5805, Bordeaux); Dannielle Tompkins (Univ. Massachusetts, USA) and Karina Gerdeau-Radonic (Univ. Bourneemouth, UK) for editing suggestions and corrections, Henri Duday (PACEA-LAPP UMR CNRS 5199, Bordeaux); Isabelle Carrère, (TRACES UMR CNRS 5608, Toulouse); Gilles Loison, Vianney Forest (INRAP Méditerranée); Jean-Pierre Giraud (SRA LanguedocRoussillon); (UMR CNRS 6578, Marseille); Eric Mahieu; M. Rigal (Musée d'Olonzac). This work was supported by the CNRS in a research program (ACR) directed by Jean Vaquer.

\section{References}

Ambrose, S.H., 1990. Preparation and characterisation of bone and tooth collagen for isotopic analysis. Journal of Archaeological Science 17, 431-451. 
Ambrose, S.H., 1993. Isotopic analysis of paleodiets: methodological and interpretative considerations. In: Sandford, M.K. (Ed.), Isotopic Analysis of Paleodiets: Methodological and Interpretative Considerations. Gordon and Breach Science Publishers, Langhorne, USA, pp. 59-130.

Balasse, M., Bocherens, H., Tresset, A., Mariotti, A., Vigne, J.-D., 1997. Emergence de la production laitière au Néolithique ? Contribution de l'analyse isotopique d'ossements de bovins archéologiques. Comptes rendus de l'Académie des sciences. Série 2. Sciences de la terre et des planètes 325, 105-1010.

Balasse, M., Tresset, A., Dobney, K., Ambrose, S.H., 2005. The use of isotope ratios to test for seaweed eating in sheep. Journal of Zoology 266, 283-291.

Balasse, M., Tresset, A., Ambrose, S.H., 2006. Stable isotope evidence (13C, 180) for winter feeding on seaweed by Neolithic sheep in Scotland. Journal of Zoology $270,170-176$

Ben-David, M., Schell, D.M., 2001. Mixing models in analyses of diet using multiple stable isotopes: a response. Oecologia 127, 180-184.

Binford, L.R., 1972. Mortuary practices: their study and their potential. In: Brown, J.A. (Ed.), Approaches to the social dimensions of mortuary practices, vol. 25. Memory of the Society of American Archaeology, Washington, pp. 6-29.

Bocherens, H., 1992. Biogéochimie isotopique $(\delta 13 \mathrm{C}, \delta 15 \mathrm{~N}, \delta 180)$ et paléontologie des vertébrés: application à l'étude des réseaux trophiques révolus et des paléoenvironnements. Ph.D. Université Paris VI, Paris.

Bocherens, H., 1997. Signature isotopique dans le collagène des os. Comptes rendus de la Société de biologie 4, 493-510.

Bocherens, H., Drucker, D., 2003. Trophic level isotopic enrichment of carbon and nitrogen in bone collagen: case studies from recent and ancient terrestrial ecosystems. International Journal of Osteoarchaeology 13, 46-53.

Bocherens, H., Drucker, D.G., 2006. Isotope evidence for paleodiet of late Upper Paleolithic humans in Great Britain: a response to Richards et al. (2005). Journal of Human Evolution 51 (4), 440-442.

Bocherens, H., Drucker, D., Billiou, D., Moussa, M., 2005a. Une nouvelle approche pour évaluer l'état de conservation de l'os et du collagène pour les mesures isotopiques (datation au radiocarbone, isotopes stables du carbone et de l'azote). L'Anthropologie 109, 557-567.

Bocherens, H., Drucker, D., Billiou, D., 2005b. Etat de conservation des ossements de la grotte Chauvet (Vallon Pont-d'Arc, Ardèche, France). Bulletin de la Société préhistorique française 102, 77-87.

Britton, K., Müldner, G., Bell, M., 2008. Stable isotope evidence for salt-marsh grazing in the Bronze Age Severn Estuary, UK: implications for palaeodietary analysis at coastal sites. Journal of Archaeological Science 35 (8), 2111-2118.

Carrère, I., Forest, V., 2003. Les Vautes et l'alimentation animale. In: Guilaine, J., Escallon, G. (Eds.), Les Vautes (Saint-Gély-du-Fesc, Hérault) et le Néolithique final du Languedoc oriental. Archives d'Ecologie Préhistoriques, Toulouse, pp. 307-333.

Chisholm, B.S., Nelson, D.E., Schwarcz, H.P., 1982. Stable isotope ratios as a measure of marine versus terrestrial protein in ancient diet. Science 216, 1131-1132.

Danforth, M.E., 1999. Nutrition and politics in Prehistory. Annual Review of Anthropology 28, 1-25.

de Labriffe, P.-A., Loison, G., Léa, V., Hasler, A., 2007. De la fosse au mégalithe, de l'individuel au collectif: les constructions funéraires entre les Ve et IVe millénaires en Languedoc oriental et en Provence. In: Moinat, P., Chambon, P. (Eds.), Les cistes de Chamblandes et la place des coffres dans les pratiques funéraires du Néolithique moyen occidental, Colloque (12-13 mai, 2006). Cahiers d'archéologie romande, Paris: Société Préhistorique Française, Lausanne, pp. 27-39.

DeNiro, M.J., 1985. Post-mortem preservation and alteration of in vivo bone collagen isotope ratios on relation to palaeodietary reconstruction. Nature 317 806-809.

DeNiro, M.J., Epstein, S., 1978. Influence of diet on the distribution of carbon isotopes in animals. Geochimica et Cosmochimica Acta 42, 495-506.

DeNiro, M.J., Epstein, S., 1981. Influence of diet on the distribution of nitrogen isotopes in animals. Geochimica et Cosmochimica Acta 45, 341-351.

Drucker, D., Henry-Gambier, D., 2005. Determination of the dietary habits of a Magdalenian woman from Saint-Germain-la-Rivière in southwestern France using stable isotopes. Journal of Human Evolution 49 (1), 19-35.

Duday, H., Vaquer, J., 2003. Les sépultures chasséennes du site des Plots Berriac (Aude). In: P. Chambon, Leclerc, J. (Eds.), Les pratiques funéraires néolithiques avant 3500 av. J.-C. en France et dans les régions limitrophes: table ronde SPF, Saint-Germain-en-Laye (15-17 June 2001), Vol. 23. Société préhistorique française, Paris, pp. 73-80.

Dufour, E., Bocherens, H., Mariotti, A., 1999. Palaeodietary implications of isotopic variability in eurasian lacustrine fish. Journal of Archaeological Science 26, 617627

Forest, V., 2000. Lots osseux fauniques archéologiques en Languedoc-Roussillon. Aperçu sur leur composition du Néolithique final au Bas Moyen Age. In: Marandet, M.C. (Ed.), L'Homme et l'animal dans les sociétés méditerranéennes. Presses Universitaires de Perpignan, Perpignan, pp. 15-26.

Goude, G., 2007. Etude des modes de subsistance de populations néolithiques (VIeIVe millénaires av. J.-C.) dans le nord-ouest de la Méditerranée. Approche par l'utilisation des isotopes stables $\left(\delta^{13} \mathrm{C}\right.$ et $\left.\delta^{15} \mathrm{~N}\right)$ du collagène. Ph.D. Université Bordeaux 1-Université de Leipzig, Talence-Leipzig.

Hedges, R., Reynard, L., 2007. Nitrogen isotopes and the trophic level of humans in archaeology. Journal of Archaeological Science 34, 1240-1251.

Helmer, D., Vigne, J.-D., 2004. La gestion des cheptels de caprinés au Néolithique dans le midi de la France. In: Bodu, P., Constantin, C. (Eds.), Approches fonctionnelles en Préhistoire: XXVe Congrès préhistorique de France, Nanterre (24-26 Novembre, 2000). Société préhistorique française, Paris, pp. 397-407.

Helmer, D., Gourichon, L., Sidi Maamar, H., Vigne, J.-D., 2005. L'élevage des caprinés néolithiques dans le sud-est de la France: saisonnalité des abattages, relations entre grottes bergeries et sites de plein air. Anthropozoologica 40 (1), 167-189.

Herrscher, E., 2003. Alimentation d'une population historique. Analyse des données isotopiques de la nécropole Saint-Laurent de Grenoble (XIIIe-XVe siècle France). Bulletins et Mémoires de la Société d'Anthropologie de Paris 15 (34), 149-269.

Herrscher, E., Le Bras-Goude, G., 2008. Viande, laitage, poissons ou végétaux. Approche biochimique de l'alimentation néolithique en Toulousain. In: Vaquer J., Gandelin, M., Remicourt, M., Tchérémissinoff, Y. (Eds.), Défunts néolithiques en Toulousain. Archives d'Ecologie Préhistorique, Toulouse, pp. 199-208.

Herrscher, E., Le Bras-Goude, G., 2010. Southern French Neolithic populations: isotopic evidence for regional specificities in environment and diet. American Journal of Physical Anthropology 141 (2), 259-272.

Jay, M., Richards, M.P., 2005. Diet in the Iron Age cemetery population at Wetwang Slack, East Yorkshire, UK: carbon and nitrogen stable isotope evidence. Journal of Archaeological Science 33 (5), 1-10.

Katzenberg, M.A., Weber, A., 1999. Stable isotope ecology and palaeodiet in the lake Baikal region of Siberia. Journal of Archaeological Science 26, 651-659.

Koch, E., Phillips, D.L., 2002. Incorporating concentration dependence in stable isotope mixing models: a reply to Robbins, Hilderbrand and Farley. Oecologia 133, 14-18.

Le Bras-Goude, G., Schmitt, A., Loison, G., 2009. Comportements alimentaires aspects biologiques et sociaux au Néolithique: le cas du Crès (Hérault, France). Comptes Rendus Palevol 8, 79-91.

Le Huray, J.D., Schutkowski, H., 2005. Diet and social status during La Tène period in Bohemia: carbon and nitrogen stable isotope anlysis of bone collagen from Kutna Hora-Karlov and Radovesice. Journal of Anthropological Archaeology 24, 135-147.

Leng, M.J., Lamb, A.L., Heaton, T.H.E., Marshall, J.D., Wolfe, B.B., Jones, M.D., Holmes J.A., Arrowsmith, C., 2006. Isotopes in lake sediments. In: Leng, M.J. (Ed.), Isotopes in Paleaeoenvironmental Research. Springer, Dordrecht, pp. 147-184

Lillie, M., 1997. Women and children in Prehistory: resource sharing and socia stratification at the Mesolithic-Neolithic transition in Ukraine. In: Moore, J. Scott, E.C. (Eds.), Invisible and Processes: Writing Gender and Chilhood into European Archaeology. Leicester University Press, London, pp. 213-228.

Linderholm, A., Jonson, C.H., Svensk, O., Lidén, K., 2008. Diet and status in Birka: stable isotopes and grave goods compared. Antiquity 82, 446-461.

Loison, A., Toïgo, C., Gaillard, G.M., 2003. Large herbivores in continental European alpine ecosystems: current status and challenges for the future. Ecological Studies 167, 351-366.

Loison, G., Fabre, V., Villemeur, I., 2004. Le Crès. Habitats préhistoriques en bordure de l'Orb. Structures domestiques et sépulture du Chasséen ancien. Rapport final d'opération, I.N.R.A.P, Montpellier.

Longin, R., 1971. New method of collagen extraction for radiocarbon dating. Nature 230, 241-242.

Mahieu, E., 1992. La nécropole de Najac à Siran (Hérault). I. Réflexion sur les sépultures chasséennes. Gallia Préhistoire 34, 141-164.

Marino, B.D., McElroy, M.B., 1991. Isotopic composition of atmospheric $\mathrm{CO}_{2}$ inferred from carbon in C4 plant celluslose. Nature 349, 127-131.

Marinval, P., 1988. L'alimentation végétale en France du Mésolithique jusqu'à l'Age du Fer. C.N.R.S, Paris

Minagawa, M., 1992. Reconstruction of human diet from $\delta 13 \mathrm{C}$ and $\delta 15 \mathrm{~N}$ in contemporary Japanese hair: a stochastic method for estimating multi-source contribution by double isotopic tracers. Applied Geochemistry 7 (2), 145-158.

Minagawa, M., Wada, E., 1984. Stepwise enrichment of ${ }^{15} \mathrm{~N}$ along food chain: further evidence and the relation between $\delta^{15} \mathrm{~N}$ and animal age. Geochimica et Cosmochimica Acta 48 (5), 1135-1140.

Müldner, G., Richards, M.P., 2005. Fast or feast: reconstructing diet in later medieval England by stable isotope analysis. Journal of Archaeological Science 32 39-48.

Murray, M.L., Schoeninger, M.J., 1988. Diet, status, and complex social structure in Iron Age Central Europe: some contributions from bone chemistry. In: Gibson, D.B., Geselowitz, M.N. (Eds.), Diet, status, and complex social structure in Iron Age Central Europe: some contributions from bone chemistry. Plenum Press, New York, USA, pp. 155-176.

Newsome, S.D., Phillips, D.L., Culleton, B.J., Guiderson, T.P., Koch, P.L., 2004. Dietary reconstruction of early to middle Holocene human population from the central California coast: insights from advanced stable isotope mixing models. Journal of Archaeological Science 31, 1101-1115.

O'Connell, T.C., Hedges, R.E.M., 1999. Investigations into the effect of diet on modern human hair isotopic values. American Journal of Physical Anthropology 108 409-425.

Parker Pearson, M., 2003. The archaeology of death and burials. Sutton, Stroud.

Phillips, D.L., Gregg, J.W., 2001. Uncertainty in source partitioning using stable isotopes. Oecologia 127, 171-179.

Phillips, D.L., Koch, P.L., 2002. Incorporating concentration dependence in stable isotope mixing models. Oecologia 130, 114-125.

Renfrew, C., Bahn, P., 2000. Archaeology: theories methods and practices. Thames et Hudson, London.

Richards, M.P., Hedges, R.E.M., Molleson, T.I., Vogel, J.C., 1998. Stable isotope analysis reveals variations in human diet at the Poundbury camp cemetery site. Journal of Archaeological Science 25, 1247-1252. 
Richards, M.P., Jacobi, R., Stringer, C., Pettitt, P.B., Cook, J., 2006. Marine diets in the European late Upper Palaeolithic: a reply to Bocherens and Drucker (2006). Journal of Human Evolution 51 (4), 443-444.

Robb, J.R.B., Lazzarini, L., Scarsini, C., Sonego, F., 2001. Social "status" and biological "status": a comparison of grave goods and skeletal indicators from Pontecagnano. American Journal of Physical Anthropology 115 (3), 213-222.

Robbins, C.T., Hilderbrand, G.V., Farley, S.D., 2002. Incorporating concentration dependence in stable isotope mixing models: a response to Phillips and Koch. Oecologia 133, 10-13.

Schoeninger, M.J., DeNiro, M.J., 1984. Nitrogen and carbon isotopic composition of bone collagen from marine and terrestrial animals. Geochimica et Cosmochimica Acta 48, 625-639.

Schoeninger, M.J., DeNiro, M.J., Tauber, H., 1983. Stable Nitrogen isotope ratios of bone collagen reflect marine and terrestrial components of prehistoric human diet. Science 220, 1381-1383.

Schurr, M.R., 1997. Stable nitrogen isotopes as evidence for the age of weaning at the Angel site: comparison of isotopic and demographic measures of weaning age. Journal of Archaeological Science 24, 919-927.

Valentin, F., Donat, R., Claustre, F., 2003. La gestion de l'espace sépulcral néolithique moyen de la grotte de Montou (Pyrénées-Orientales): un essai d'interprétation. Le Bulletin de la Société Préhistorique Française 23, 301-314. van Klinken, G.J., 1999. Bone collagen quality indicators for palaeodietary and radiocarbon measurements. Journal of Archaeological Science 26, 687-695.

van Klinken, G.J., Richards, M.P., Hedges, R.E.M., 2000. An overview of causes for stable isotopic variations in past European human populations: environmental ecophysiological and cultural effects. In: Ambrose, S.H., Katzenberg, M.A. (Eds.), Biogeochimical Approaches to Paleodietary Analysis. Kluwer, New York, pp. 3958.

Vaquer, J., 1990. Le Néolithique en Languedoc Oriental. C.N.R.S, Paris

Vaquer, J., 1998. Les sépultures du Néolithique moyen en France méditerranéenne. In: Guilaine, J. (Ed.), Sépultures d'occident et genèse des magalithismes (95003500). Errance, Paris, pp. 167-186.

Vaquer, J., 2007. Les tombes à dalles du Néolithique moyen dans la zone nord pyrénéenne. In: Moinat, P., Chambon, P. (Eds.), Les cistes de Chamblandes et la place des coffres dans les pratiques funéraires du Néolithique moyen occidental, Colloque (12-13 mai 2006). Cahiers d'archéologie romande, Lausanne. Société Préhistorique Française, Paris, pp. 13-25.

Vaquer, J., Duday, H., Gandelin, M., Tresset, A., Herouin, S., 2007. La tombe de Coste Rouge, Beaufort (Hérault) et la question des tombes à dalles néolithiques dans le nord-est des Pyrénées. Gallia Préhistoire 49, 127-159. 